\title{
Ética na Pesquisa com Crianças / Ethics on Research with Children
}

https://doi.org/10.21814/uminho.ed.36.28 



\section{Ética na Pesquisa com Crianças ${ }^{6}$}

O significativo desenvolvimento que a investigação com crianças tem tido nas duas últimas décadas, a partir da área da Sociologia da Infância, tem vindo a mobilizar reflexão acerca de pressupostos éticos que confiram aos processos de investigação rigor e cientificidade, para além de respeito pelo sujeito criança.

Sustentando-se nos pressupostos mais clássicos que provêm da Declaração de Helsínquia de 1964 e da Convenção de Oviedo de 1997, a ética na investigação com crianças tem vindo a defender processos de pesquisa que acautelem o seu superior interesse.

Argumentamos que o desenvolvimento de pesquisas com crianças, eticamente informadas, impõe considerar o pressuposto fundacional da criança enquanto sujeito ativo de direitos, portadora de singularidades, que exige da parte do investigador uma significativa imaginação metodológica, quer relativamente aos métodos escolhidos para o desenvolvimento da pesquisa, quer à exigência de ir além de uma ética a la carte passível de ser replicada, exigindo uma contínua reflexividade para lidar com novos dilemas éticos e novas responsabilidades. Se defendemos que a criança é um sujeito ativo de direitos, interlocutora relevante e especialista nas leituras dos seus mundos de vida, como é que os processos de pesquisa que desenvolvemos com elas se devem caracterizar?

Desde logo, os processos de pesquisa eticamente informados devem considerar a Convenção sobre os Direitos da Criança enquanto documento orientador, a partir dos quatro princípios que trespassam o conjunto de direitos que nela estão incluídos: Não discriminação; Superior interesse da criança; Participação, e Sobrevivência e Desenvolvimento. No que diz respeito ao princípio da Não Discriminação, deveremos questionarmos de que modo

\footnotetext{
$6 \mathrm{~A}$ investigadora é financiada por Fundos Nacionais através da FCT - Fundação para a Ciência e a Tecnologia no âmbito dos projetos do CIEC (Centro de Investigação em Estudos da Criança da Universidade do Minho) com as referências UIDB/00317/2020 e UIDP/00317/2020.

The researcher was financially supported by Portuguese national funds through the FCT (Foundation for Science and Technology) within the framework of the CIEC (Research Center for Child Studies of the University of Minho) projects under the references UIDB/00317/2020 and UIDP/00317/2020.
} 
os processos de pesquisa acautelam a não exclusão ou discriminação das crianças, mantendo uma vigilância a dimensões que vão desde as questões de género, às questões etárias, ou ainda às questões de etnia ou de classe social. No que diz respeito ao Superior interesse da criança, e indo de encontro ao proposto no comentário Geral n. ${ }^{\circ} 14$ (2013), deveremos questionar até que ponto os processos de pesquisa que desenvolvemos com crianças sustentam que, na tomada de decisões acerca das opções metodológicas, deverão prevalecer aquelas que menor dano e maiores ganhos tragam para as crianças, em primazia dos adultos. No que diz respeito à Participação, os processos de pesquisa deverão acautelar possibilidades para que as opiniões e perspetivas das crianças possam ser respeitadas, mobilizando para tal um conjunto de procedimentos metodológicos que permitam que as crianças possam expressar os seus pontos de vista. Finalmente, no que diz respeito ao princípio da Sobrevivência e desenvolvimento, deveremos ter sempre presente o dever de assegurar que os processos de pesquisa não provocam situações de impacto danoso para as crianças e assegurem o seu bem-estar.

Estes pressupostos orientadores da ação do pesquisador implicam um profundo conhecimento teórico, empírico e formal-jurídico, de modo a acautelar que as crianças possam assumir visibilidade e autoria, sem nunca descurar a sua proteção e o respeito pelo seu interesse superior.

A Carta Internacional de Pesquisa Ética com Crianças ${ }^{7}$ (2013) desenvolvida pela Childwatch International identifica um conjunto de aspetos relacionados com o facto de que a ética na pesquisa com crianças é responsabilidade de todos; que respeitar a dignidade das crianças é central para uma pesquisa ética; que a pesquisa com crianças tem de ser justa e equitativa e beneficiar as crianças; que as crianças nunca devem ser prejudicadas pela sua participação na pesquisa; que a pesquisa deve sempre considerar o consentimento inicial e contínuo e, finalmente, que a pesquisa requer uma constante reflexividade.

A partir da Sociologia da Infância compreendemos que os processos de pesquisa respeitadores do interesse superior da criança, pugnam pela impor-

7 Carta Internacional para Pesquisa Ética Envolvendo Crianças é uma declaração de sete compromissos principais que visam elevar o estatuto, os direitos e o bem-estar de todas as crianças envolvidas em pesquisas. Foi escrito com e para pesquisadores e outros que estão comprometidos com as crianças e com o cumprimento das suas responsabilidades em realizar pesquisas éticas e de qualidade, independentemente do contexto. https://www.childwatch.uio.no/news/2013/international-charterpara-ética-pesquisa-envolvi.html 
tância da não interferência e evitar causar dano deliberado, mas também pelos riscos advêm da sobre proteção das crianças quando as silenciamos ou excluímos da pesquisa (Alderson \& Morrow, 2011). O percurso que tem sido feito a este propósito é crítico relativamente a dimensões mais clássicas que se preocupam fundamentalmente com uma gestão cautelosa do risco, reduzindo-se, muitas vezes, os cuidados éticos a meros procedimentos formais de gestão do risco (Allen, 2005). É fundamental ir além de posicionamentos acríticos, mobilizados por muitos comités de ética, pois eles são contraditórios com os referenciais teóricos que sustentam a maior parte destes estudos e que apresentam a criança como ator social portador de voz. Tal como temos vindo a defender é fundamental ir além do éticocídio de conhecimento (Fernandes, 2016), ou seja, é crucial enfrentar processos formais burocráticos, a partir dos conselhos éticos de pesquisa que, em muitos casos, não partilhando dos pressupostos epistemológicos das pesquisas que propõem a participação das crianças no seu desenvolvimento, impedem a mesma sob o argumento da proteção ou então da incompetência das mesmas no processo de pesquisa, nos processos de construção de conhecimento acerca de si, desvalorizando as suas perspetivas, a sua autoria, subalternizando-se assim as perspetivas das crianças em detrimento das dos adultos, invisibilizando, dessa forma, a riqueza que adviria dos seus contributos e heterogéneas visões e perspetivas.

O sociólogo da infância deve defender processos de pesquisa eticamente informados em que os protocolos, tal como os procedimentos, não são fixos, mas sim permanentemente ativos e renegociados, de acordo com as características das crianças, dos adultos, dos contextos, bem como ainda das questões de investigação e dos métodos de pesquisa. Uma investigação ética com crianças deve ter sempre como princípio orientador que a criança deve ser respeitada na sua condição de sujeito ativo de direitos, de autora.

\section{Ethics in the Research with Children}

A significant development that research with children has revealed in the last two decades, stemming from the area of the sociology of childhood, has been the raising of awareness of the ethical requirements of the research process regarding its accuracy, scientific standing and the respect for the subject child. Based of the classic requirements emerging from the Declaration of Helsinki of 1964 and the Convention of Oviedo of 1997, ethics in research with children has been defending research processes that have children's interests at heart. 
We reason that the development of ethically informed research with children, necessitates considering the fundamental requirement of the child as an active subject of rights, as an individual, which demands from the researcher a significant methodological imagination and flexibility. This includes the methods chosen for the development of the research, as well as the expectation that the researcher goes beyond an a la carte ethic that can be replicated, thereby demanding a continuous flexibility in dealing with new ethical dilemmas and responsibilities. If we maintain that children are active subjects of rights, relevant interlocutors and experts in their own worlds and lives, we must question how research processes that we develop with them should be organized.

Firstly, ethically informed research processes should follow the Convention on the Rights of the Child as their guiding document, taking into account the four principles that derive from the Convention's set of rights: Non-Discrimination; the child's best interests; participation; and survival and development. Regarding the principle of Non-Discrimination, we should question how research processes ensure that children are not excluded or discriminated against, while remaining vigilant about gender issues, age and ethnicity issues and social class issues.

In terms of the best interests of the child and agreeing with the General Comment nr. 14 (2013), we must question the extent to which research processes with children have selected the methodological options that cause less damage to and greater gains for children rather than adults.

On the question of participation, research processes should promote strategies to ensure that the options and perspectives of children can be respected, by using a set of methodological procedures that allow children to express their points of view. Finally, regarding Survival and Development, we should always take into account the responsibility of making sure that the research processes do not cause harmful situations for the children and, instead, ensure their well-being.

These guiding requirements of the researcher's action imply a deep theoretical, empirical and legal knowledge, in order to ensure that children remain visible and have ownership, without ever neglecting their protection and the respect for their best interests.

The International Charter of Ethical Research with Children (2013) developed by Childwatch International identifies a group of features related 
to the fact that ethics in research with children is a global responsibility; that respecting the dignity of children is central to ethical research; that research with children must be just, equitable and benefit the subject; that children should never be harmed by their participation in research; that the research must always seek initial and continuous consent, and, finally, that research requires constant reflexivity.

From the sociology of childhood, we understand that research processes respectful of the child's best interest strive for the importance of non-interference and avoid causing deliberate harm, but also consider the risks that come from overprotecting children by silencing and excluding them from research (Alderson \& Morrow, 2011). The sociology of childhood is critical of more classic perspectives which are primarily concerned with a cautious risk assessment, often minimizing the ethical care given to mere formal procedures of risk management (Allen, 2005). It is essential to go beyond uncritical positions, constrained by various ethics committees, as they are contradictory to the theoretical frameworks that support most of these studies and that present the child as a social actor with a voice.

As we have asserted, it is fundamental to go beyond the ethicocide of knowledge (Fernandes, 2016), that is, challenging formal bureaucratic processes, based on ethic research councils, which in many cases, do not share the epistemological requirements of research that proposes children's participation in its development. These bureaucratic processes prevent participation under the argument of protection. Their incompetence in the research process, in refusing to allow children the ability to build knowledge about themselves, in devaluing their perspectives and authority, in subordinating children's perspectives to the control of the adults, thus, renders invisible the richness of children's contributions and their heterogeneous views and perspectives.

The childhood sociologist must defend ethically informed research processes in which protocols, as well as procedures, are not fixed, but permanently active and negotiated according to the characteristics of the children, the adults, and the contexts as well as the research questions and methods. Ethical research with children must always have as a guiding principle that the child should be respected as an active subject of rights and, as an autonomous being. 


\section{Referências / References}

Alderson, P., \& Morrow, V. (2011). The Ethics of Research with Children and Young People: A Practical Handbook. London: Sage, 3rd edition.

Allen, G. (2005). Research ethics in a culture of risk. In A. Farrell (Ed.), Ethical research with children (pp. 15-26). Trowbridge, GB: Open University Press.

Fernandes, N. (2016). Ética na pesquisa com crianças: ausências e desafios. Revista Brasileira de Educação, 21(6),759-779. http://dx.doi.org/10.1590/S1413-24782016216639. 